\title{
Acupuncture for low back pain
}

Roselyn Clemente Fuentes MD FAAFP FAWM Brooke Organ Do Julie Creech do Christine M. Broszko mD Joan Nashelsky mLS

\section{Clinical Inquiries question}

Is acupuncture effective in improving pain relief for low back pain?

\section{Evidence-based answer}

Acupuncture is an effective treatment for relief from low back pain, even when compared with other interventions (sham acupuncture, usual care, or no treatment), with stronger effects observed immediately after treatment. Clinically significant reduction in pain is more reliably observed in chronic rather than acute low back pain (strength of recommendation: A, based on systematic review and meta-analysis of randomized controlled trials [RCTs]).

\section{Evidence summary}

The literature search was completed between January and July 2019. Findings are outlined in Table $1 .^{1-4} \mathrm{~A}$ 2015 systematic review and meta-analysis ${ }^{1}$ of 31 RCTs $(\mathrm{N}=6656)$ comparing acupuncture with other treatments (sham acupuncture, no treatment, transcutaneous electrical nerve stimulation, medications, usual care) found that acupuncture was clinically superior to sham acupuncture in pain reduction for patients with chronic low back pain (CLBP) - defined as lasting longer than 3 months-immediately after (standardized mean difference [SMD] of $-0.49,95 \% \mathrm{CI}-0.76$ to -0.21 ) and up to 3 months following (SMD $=-0.45,95 \%$ CI -0.76 to -0.14 ) treatment. Further, acupuncture provided more pain relief in CLBP compared with no treatment $(\mathrm{SMD}=-0.73$, 95\% CI -0.96 to -0.49 ) and usual care, which typically consisted of nonacupuncture care like physical therapy, massage, and medication (mean difference [MD] of $-11.47,95 \%$ CI -19.33 to $-3.61, I^{2}=59.9 \%$ ) immediately following treatment. Analysis of studies comparing acupuncture with medications and transcutaneous electrical nerve stimulation treatment found no significant differences in pain reduction. ${ }^{1}$ Effects on pain and function were reported on a 100-point visual analogue scale (VAS).

Table 1. Summary of the evidence for acupuncture for low back pain

\begin{tabular}{|c|c|c|}
\hline STUDY TYPE & POPULATION & OUTCOMES* \\
\hline $\begin{array}{l}\text { Systematic review } \\
\text { and meta-analysis }{ }^{1} \\
\text { (31 RCTs) }\end{array}$ & $\begin{array}{l}\text { - } \mathrm{N}=6656 \\
\text { - Age } 17-90 \text { y } \\
\text { - } 40 \% \text { male, } 60 \% \text { female } \\
\text { - Excluded LBP caused by } \\
\text { trauma, infection, } \\
\text { fracture, tumour, } \\
\text { fibromyalgia, cauda } \\
\text { equina syndrome }\end{array}$ & $\begin{array}{l}\text { - Acupuncture clinically superior to sham acupuncture in immediate pain } \\
\text { reduction for chronic LBP }(S M D=-0.49,95 \% \mathrm{Cl}-0.76 \text { to }-0.21) \\
\text { - Acupuncture clinically superior to sham acupuncture } 3 \text { mo following } \\
\text { treatment for chronic LBP }(S M D=-0.45,95 \% \mathrm{Cl}-0.76 \text { to }-0.14) \\
\text { - Acupuncture clinically superior compared with no treatment for chronic LBP } \\
(\mathrm{SMD}=-0.73,95 \% \mathrm{Cl}-0.96 \text { to }-0.49) \\
\text { - Acupuncture clinically superior compared with usual care in immediate pain } \\
\text { reduction for chronic LBP }\left(\mathrm{MD}=-11.47,95 \% \mathrm{Cl}-19.33 \text { to }-3.61, l^{2}=59.9 \%\right)\end{array}$ \\
\hline $\begin{array}{l}\text { Appraisal of } \\
\text { systematic reviews }{ }^{2} \\
\text { (16 systematic } \\
\text { reviews of RCTs) }\end{array}$ & $\begin{array}{l}\cdot \mathrm{N}=11682 \\
\cdot \text { Age > } 18 \mathrm{y}\end{array}$ & $\begin{array}{l}\text { - Acupuncture statistically but not clinically superior to sham acupuncture or } \\
\text { usual care in immediate pain reduction for acute } \operatorname{LBP}(\mathrm{MD}=-9.38,95 \% \mathrm{Cl} \\
\left.-17.00 \text { to }-1.76, P=.02, I^{2}=27 \%\right) \\
\text { - Acupuncture clinically superior to sham acupuncture or usual care in } \\
\text { immediate pain reduction for chronic } \mathrm{LBP}(\mathrm{WMD}=-5.88,95 \% \mathrm{Cl}-11.20 \text { to } \\
-0.55 \text {, at } 1 \mathrm{mo} \text {; and } W M D=-17.79,95 \% \mathrm{Cl}-25.50 \text { to }-10.0 \text {, at } 3 \mathrm{mo})\end{array}$ \\
\hline $\begin{array}{l}\text { Systematic review3 } \\
\text { (17 RCTs) }\end{array}$ & $\begin{array}{l}\text { - } \mathrm{N}=7958 \\
\text { - Age }>18 \text { y } \\
\text { - Excluded LBP related to } \\
\text { cancer, infection, } \\
\text { inflammatory } \\
\text { arthropathy, trauma, } \\
\text { fracture, pregnancy, } \\
\text { neurologic deficits } \\
\text { - Included radicular and } \\
\text { nonradicular pain }\end{array}$ & $\begin{array}{l}\text { - Acupuncture statistically superior to sham acupuncture in immediate pain } \\
\text { reduction for chronic LBP (WMD }=-16.76,95 \% \mathrm{Cl}-33.3 \text { to }-0.19 \text { ) } \\
\text { - Acupuncture statistically superior to sham acupuncture } 3 \text { mo following } \\
\text { treatment for chronic low back (WMD }=-9.55,95 \% \mathrm{Cl}-16.5 \text { to }-2.58) \\
\text { - Acupuncture statistically superior compared with medications for chronic } \\
\text { LBP (WMD }=-10.56 \text { on } 0 \text { - to } 100 \text {-point scale, } 95 \% \mathrm{Cl}-20.34 \text { to }-0.78) \text { and } \\
\text { improved function ( } 3 \text { trials, } \mathrm{SMD}=-0.36,95 \% \mathrm{Cl}-0.67 \text { to }-0.04) \\
\text { - Seven } \mathrm{RCTs} \text { studying immediate effects on pain reduction }(4 \text { trials, } \\
\mathrm{SMD}=-0.72,95 \% \mathrm{Cl}-0.94 \text { to }-0.49) \text { and function ( } 3 \text { trials, SMD }=-0.94,95 \% \mathrm{Cl} \\
-1.41 \text { to }-0.47) \text { favoured acupuncture over control with no acupuncture }\end{array}$ \\
\hline
\end{tabular}


A 2015 appraisal of 16 systematic reviews of RCTs $(\mathrm{N}=11682)$ comparing acupuncture with sham acupuncture, no treatment, or acupuncture plus conventional treatment, which included physical therapy, exercise, and medication, revealed inconsistent evidence of benefit in acute low back pain-defined as lasting less than 3 months-with studies supporting statistically but not clinically relevant pain relief immediately after intervention (MD $=-9.38,95 \% \mathrm{CI}-17.00$ to $-1.76 ; P=.02 ; I^{2}=27 \%$ ). Acupuncture was consistently found to provide superior pain relief for CLBP lasting greater than 3 months in the short term (weighted mean difference [WMD] of -5.88 , $95 \%$ CI -11.20 to -0.55 , at 1 month; and $W M D=-17.79$, 95\% CI -25.50 to -10.07 , at 3 months). ${ }^{2}$ Effects on pain and function were reported on a 100-point VAS, the Roland Morris Disability Questionnaire, the Oswestry Disability Index, and the Quebec Back Pain Disability Scale, which were consolidated by distribution-based methods to determine clinical relevance.

A 2016 systematic review $(\mathrm{N}=7958)$ including 7 RCTs of acupuncture versus sham acupuncture for CLBP lasting longer than 3 months found that acupuncture significantly reduced pain intensity immediately (4 trials, $\mathrm{WMD}=-16.76,95 \% \mathrm{CI}-33.3$ to -0.19$)$ and 12 weeks after treatment ( 3 trials, $\mathrm{WMD}=-9.55,95 \% \mathrm{CI}-16.5$ to -2.58 ). Seven RCTs studying immediate effects on pain reduction ( 4 trials, $\mathrm{SMD}=-0.72,95 \% \mathrm{CI}-0.94$ to -0.49 ) and function (3 trials, SMD $=-0.94,95 \% \mathrm{CI}-1.41$ to -0.47 ) favoured acupuncture over control with no acupuncture. Compared with medications (nonsteroidal anti-inflammatory drugs, muscle relaxants, or analgesics), acupuncture provided greater pain relief ( 3 trials, $\mathrm{WMD}=-10.56$ on a 0 - to 100 point scale, $95 \% \mathrm{CI}-20.34$ to -0.78 ) and improved function ( 3 trials, $\mathrm{SMD}=-0.36,95 \% \mathrm{CI}-0.67$ to -0.04$).{ }^{3}$ Effects on pain and function were reported on a 100-point VAS and the Roland Morris Disability Questionnaire.

Common limitations in the appraised studies were small numbers of trials and methodologic heterogeneity regarding acupuncture techniques, number and duration of treatments, and type of sham acupuncture used. ${ }^{1-3}$ One review noted that sham acupuncture as a control was particularly problematic because neither noninsertion nor superficial insertion at nonacupoints is fully physiologically inert. ${ }^{2}$

\section{Recommendations from others}

The American College of Physicians issued a clinical practice guideline recommending acupuncture as a first-line therapy for acute and chronic nonradicular low back pain along with other nondrug therapy including stretching, heat application, massage, and manual spinal manipulation. ${ }^{5}$ The National Institutes of Health's National Center for Complementary and Integrative Health considers acupuncture to be a safe treatment when done by trained acupuncturists using sterile needles. ${ }^{6}$

Dr Organ is an osteopath and family medicine resident, Dr Creech is an osteopath and family medicine resident, Dr Clemente Fuentes is a family physician, and Dr Brozsko is a family physician, all in the Eglin Family Medicine Residency program at Eglin Air Force Base in Florida. Ms Nashelsky is a medical librarian with the Family Physicians Inquiries Network in lowa City, lowa.

\section{Competing interests}

None declared

\section{Correspondence}

Dr Roselyn Clemente Fuentes; e-mail roselynjan.w.fuentes.mil@mail.mi

The opinions and assertions contained herein are those of the authors and are not to be construed as official or as reflecting the views of the US Air Force Medical Department, the Air Force at large, or the Department of Defense.

\section{References}

1. Yuan QL, Guo TM, Liu L, Sun F, Zhang YG. Traditional Chinese medicine for neck pain and low back pain: a systematic review and meta-analysis. PLoS One 2015;10(2):e0117146.

2. Liu L, Skinner MA, McDonough S, Mabire L, Baxter GD. Acupuncture for low back pain: an overview of systematic reviews. Evid Based Complement Alternat Med 2015;2015:328196. Epub 2015 Mar 4.

3. Chou R, Deyo R, Friedly J, Skelly A, Hashimoto R, Weimer M, et al. Noninvasive treatments for low back pain. Rockville, MD: Agency for Healthcare Research and Quality; 2016. Available from: https://effectivehealthcare.ahrq.gov/sites/default/files/pdf/ back-pain-treatment_research.pdf. Accessed 2020 Feb 11.

4. Cohen J. A power primer. Psychol Bull 1992;112(1):155-9.

5. Qaseem A, Wilt TJ, McLean RM, Forciea MA; Clinical Guidelines Committee of the American College of Physicians. Noninvasive treatments for acute, subacute, and chronic low back pain: a clinical practice guideline from the American College of Physicians. Ann Intern Med 2017;166(7):514-30. Epub 2017 Feb 14.

6. National Center for Complementary and Integrative Health. Acupuncture: in depth. Bethesda, MD: National Institutes of Health; 2016. Available from: https://nccih.nih. gov/health/acupuncture/introduction. Accessed 2019 Aug 11.

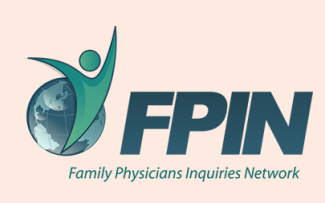

Clinical Inquiries are author-formulated questions that are answered with the best available current evidence, written by family medicine residency faculty and their residents through the Family Physician Inquiries Network. The strength of recommendations and the level of evidence for individual studies are rated using criteria developed by the EvidenceBased Medicine Working Group (www.cebm.net). The Family Physicians Inquiries Network Clinical Inquiries series in Canadian Family Physician is coordinated by Rick Guthmann, MD, MPH, Editor-in-Chief for the series. If interested in submitting questions or writing answers for this series, go to www.fpin.org or e-mail ci@fpin.org. (c) Family Physicians Inquiries Network. Used with permission. 